\title{
GLOBAL INCOME INEQUALITY: WHAT IT IS AND WHY IT MATTERS
}

\author{
Branko Milanovic $^{1}$
}

\begin{abstract}
The paper presents a non-technical summary of the current state of debate on the measurement and implications of global inequality (inequality between citizens of the world). It discusses the relationship between globalization and global inequality. It shows why global inequality matters and proposes a scheme for global redistribution.
\end{abstract}

JEL classification: D31

Key words: globalization, global inequality, aid Number of words: about 9100.

World Bank Policy Research Working Paper 3865, March 2006

The Policy Research Working Paper Series disseminates the findings of work in progress to encourage the exchange of ideas about development issues. An objective of the series is to get the findings out quickly, even if the presentations are less than fully polished. The papers carry the names of the authors and should be cited accordingly. The findings, interpretations, and conclusions expressed in this paper are entirely those of the authors. They do not necessarily represent the view of the World Bank, its Executive Directors, or the countries they represent. Policy Research Working Papers are available online at http://econ.worldbank.org.

\footnotetext{
${ }^{1}$ World Bank, Development Research Group. I would like to thank Francisco Ferreira, K.S. Jomo, and Paul Segal for very helpful comments. Email: bmilanovic@worldbank.org.
} 
1. What is global inequality?

Global inequality is a relatively recent topic. The first calculations of inequality across world citizens were done in the early 1980s. ${ }^{2}$ This is because in order to calculate global inequality, one needs to have data on (within-)national income distributions for most of the countries in the world, or at least for most of the populous and rich countries. But it is only from the early- to mid-1980s that such data became available for China, ${ }^{3}$ the Soviet Union and its constituent republics and large parts of Africa. Before we move to an analysis of global inequality, however, it is useful to set the stage by delineating what topics we shall be concerned with and what not. This is necessary precisely because of the relative underdevelopment of the topic, reflected in the fact that the same or similar terms are often used in the literature to mean different things. We need to distinguish between inequality among countries' mean incomes (inter-country inequality or Concept 1 inequality as dubbed by Milanovic, 2005), inequality among countries' mean incomes weighted by countries' populations (Concept 2 inequality), and inequality between world individuals (global or Concept 3 inequality).

Concept 1 inequality deals with convergence and divergence of countries and although at first this line of work was couched in inequality terms (see Baumol 1986), most of the later work used cross-country regressions and $\beta$ convergence. ${ }^{4}$ In such regressions each country/year is one observation. This line of research, which has generated a huge literature, is interesting for a number of reasons but it has very little to tell us about income inequality among world citizens. This is basically because countries are of unequal population size. Thus a fast increase in income of a small poor country

\footnotetext{
${ }^{2}$ By Berry, Bourguignon and Morrisson (1983), and Grosh and Nafziger (1986).

${ }^{3}$ The first post-Cultural Revolution household survey in China was conducted in 1978. The first available rural and urban surveys are from respectively 1980 and 1981 (see Ravallion and Chen, 2006, forthcoming, p. 3).

${ }^{4}$ Some of the initial emphasis on inequality rather than on the $\beta$ coefficients can still be seen in the use of the sigma convergence where sigma is the standard deviation of income logs.
} 
will not have the same effect on global inequality as the same per capita increase in a poor and populous country.

Concept 2 inequality tries to take this into account by weighing each country by its population. It is a natural and low-cost approach since it requires the knowledge of only two variables: mean income, which is approximated by GDI per capita, and population size. The first such calculations were done by Kuznets in 1954 (see Kuznets, 1965, pp. 162ff). ${ }^{5}$ Some thirteen years later, Kravis, Heston and Summers (1978), as part of their first study of purchasing power parity, calculated Concept 2 inequality for the non-socialist world. There are two reasons for the enduring popularity of this approach (for recent examples, see Schultz 1988, Boltho and Toniolo 1999, Firebaugh 2003). First, Concept 2 inequality is the largest component of global inequality. Global inequality is by definition composed of population-weighted international inequality (Concept 2 or between-inequality), and inequality due to income differences within countries. The relationship is shown in equations (1) and (2) for respectively Gini and Theil coefficients, where $y_{i}=$ per capita income of the $i$-th country, $p_{i}=$ population share of the $i$-th country in total world population, $\pi_{\mathrm{i}}=$ share of the $i$-th country in total global income, $\mathrm{n}=$ number of countries, $\mathrm{G}_{\mathrm{i}}=$ Gini coefficient of national income distribution, $\mathrm{T}_{\mathrm{i}}=$ Theil coefficients of national income distribution, and $\mathrm{L}=$ the so-called overlapping component. ${ }^{6}$ Since the between component is by far the larger, accounting for between two-thirds and three-quarters of global inequality (depending on inequality measure), Concept 2 inequality can be used as a lower-bound proxy for global inequality. Moreover its movements can be supposed to track changes in global inequality. Second, the data requirements for the calculation of Concept 2 inequality are modest.

\footnotetext{
${ }^{5}$ For the year 1949, Kuznets calculated a Concept 2 inequality that covered around a third of world population.

${ }^{6}$ The overlapping component accounts for the fact that somebody who lives in a richer country may have an income lower than somebody from a poorer country (and the reverse). L is calculated as a residual and this is why Gini index is, unlike Theil, not exactly decomposable.
} 


$$
\text { Concept_3_Gini }=\sum_{i=1}^{n} G_{i} p_{i} \pi_{i}+\frac{1}{\mu} \sum_{i}^{n} \sum_{j>i}^{n}\left(y_{j}-y_{i}\right) p_{i} p_{j}+L
$$

Concept 2 Gini

$$
\text { Concept_3_Theil }=\sum_{i=1}^{n} p_{i} T_{i}+\sum_{i=1}^{n}\left(p i \frac{y i}{\mu}\right) \ln \frac{y i}{\mu}
$$

What Concept 2 inequality does not take into account are within-national inequalities. In calculating Concept 2 inequality, we implicitly assume that each individual within a country has the same per capita income (and thus $\mathrm{G}_{\mathrm{i}}=\mathrm{T}_{\mathrm{i}}=\mathrm{L}=0$ ). This last assumption needs to be abandoned if we want to calculate "true" global inequality across individuals. But in order to abandon it, one must have access to national income distributions which are available only from household surveys. It is this "jump" that makes such a big difference in data requirements between Concept 2 and Concept 3 . From being "modest", the data requirements now become huge since, ideally, we should have access to national income distributions from all the countries in the world. 
This leads to a very important, albeit not sufficiently appreciated, difference between Concepts 2 and 3. This is not a conceptual difference but rather the difference in what is a commonly used metric of welfare. To be sure, Concept 2 inequality can be calculated across GDIs per capita or across mean disposable incomes retrieved from countries' household surveys (HS). It is however almost never calculated using the latter because HS means are much more difficult to obtain than National accounts (NA) data. In contrast, Concept 3 inequality must be based on household surveys because the only source of distributional data are, as said before, household surveys. Because there is no world-wide household survey this means that the best one can do is to combine individual countries' surveys, and use disposable per capita income or personal per capita consumption as welfare indicators.

Now, the problem is first, that there is a definitional difference between GDI which comes from National accounts, and disposable income which comes from surveys, and second, that there was a recent tendency for these two measures not to move in unison in several important countries (see Deaton, 2005). Thus, even if everything else were fully comparable, a commonly calculated Concept 2 measure that uses National accounts data would differ from an equivalent Concept 2 measure calculated using household surveys because welfare indicators are different and because they have recently diverged for reasons that are not yet quite clear. ${ }^{7}$

This review will deal only with studies of global or Concept 3 income inequality. ${ }^{8}$ The easiest point of departure for an estimate of global inequality is to calculate Concept

\footnotetext{
${ }^{7}$ This area - understanding why national accounts and household surveys averages move differentlyrepresents one of the most important areas for further research. Bhalla (2001) must be credited through his, at times single-minded, insistence on using National accounts data for highlighting this issue.

${ }^{8}$ And with global inequality conventionally defined as inequality in relative, not absolute, incomes and using the conventional measures of inequality like the Lorenz curve, Gini coefficient or Theil index. The focus on absolute inequality however has its own uses (see Atkinson and Brandolini, 2004; Svedberg, 2003; Ravallion 2004). Similarly, relative income inequality with the use of different inequality aversion parameters (reflecting in principle different welfare judgments) will produce ambiguous results even where conventional statistics yield a clear outcome (see Capeau and Decoster, 2004, Table 5).
} 
2 inequality using NA data and combine it with the empirical observation that withinnational income distributions tend to follow a log-normal pattern. Then the only additional piece of information needed is a Gini coefficient or some other summary inequality statistic describing national income distributions. They are published in various compendia of the Gini coefficients such as WIDER, the Deininger-Squire database etc. ${ }^{9}$ Under the assumption of lognormal distribution of income, the inequality statistics allow us to retrieve an estimate of the variance of each national distribution. Once we know the variance and the mean, and given the assumption of log-normality, we can estimate the entire distribution, that is, each fractile's income. It is then a relatively simple task to combine these national distributions into a single world-wide income distribution, particularly so if one uses an exactly decomposable measure of inequality like the Theil coefficient or the variance of logs. This was precisely the approach followed by many early and some recent studies of global inequality (Berry, Bourguignon and Morrison, 1983; Grosh and Nafziger 1986; Quah 1999; Shultze 1998; Chotikapanich et al. 1997). At times this approach can be refined by using a bit more information than what is contained in a Gini or Theil index. Sala-i-Martin and Bhalla have used quintiles of income distribution to get a better handle on national distributions and thus a more precise estimate of global distribution. All these methods can be considered tatonnements, groping for the global distribution.

These methods are quite ingenious given their rather minimal information requirements. But they are also very "costly" because it is often the numerous assumptions, piled up one upon another, that drive the results rather than the data. A lot of assumptions are made simultaneously (e.g. that each country's distribution is lognormal; that GDP per capita gives the correct mean income and that its under- or overestimation compared to household surveys is constant across poor and rich alike) and it is quasi impossible to tell the impact which each of the assumptions separately has on the results. Further, since even the minimal data requirements (national Ginis) are not satisfied annually, authors are led to make additional assumptions (for example, that national inequality does not change or changes in an assumed fashion), so that at the end

\footnotetext{
${ }^{9}$ Available at http://www.wider.unu.edu/wiid/wiid.htm and http://econ.worldbank.org.
} 
the part of the results driven by various assumptions may vastly outstrip the part based on actual data. The best recent examples of such approaches, which are often thinly disguised Concept 2 inequality calculations, are Bhalla (2002) and Sala-i-Martin (2002). In Bhalla's (2001) calculations of global inequality only one out of every 24 distributions is based on actual data and 23 are "derived" through assumptions; in Sala-i-Martin's (2002) paper, the ratio is 1 actual to 4 "derived" distributions. ${ }^{10}$

The quantum leap compared to this method is to use directly household surveys from as many (ideally all) countries of the world. This was done by Milanovic (2002; 2005) and World Bank (2005). Here in principle global inequality is calculated the same way as one calculates within-country inequality, using not National accounts data, but surveys. Another quantum leap in this line of research will occur when these, so far disparate, national surveys are standardized or a single world-wide household survey is conducted. We shall come back to this in Section 3. Now we have to cover briefly some methodological issues that are indeed very important in this type of research although they seldom receive the attention they deserve.

${ }^{10}$ For a critique, see Milanovic (2002a and 2005, pp. 119-127). 
2. Some methodological issues

We start with the simplest question of all: what is "income" in the calculations of global inequality? As we have seen, most of the early work used national accounts data, that is GDI per capita expressed in the same currency (international or PPP dollars). This is because household survey data for many countries of the world were simply unavailable (and even when they existed, researchers could not get them because the statistical agencies refused to release them). ${ }^{11}$ There are currently three main sources of world wide data on GDI per capita across time and across countries. They are World Bank data available in World Bank World Development Indicators (WDI), Penn World Tables, and Angus Maddison's data. The advantage of using GDI per capita as "income" is that these numbers, even if the three sources do not always agree among themselves, are relatively uncontroversial. We know what is meant by GDI per capita and we know that these values do give some generally accepted mean incomes of all nations. ${ }^{12}$

The main drawback of this approach is that GDI per capita is not "income" in any recognizable sense to any individual or household. Gross domestic income includes components such as corporate investment from retained profits, build-up of stocks, government spending on defense etc., which are not part of an even broadly defined household disposable income. In addition, publicly-financed health and education are part of GDI per capita but not included in household per capita disposable income unless one is able to impute - which is quasi impossible in a multi-country context - these values back to individual households based on survey data on their school attendance and use of medical services.

\footnotetext{
${ }^{11}$ This is still the case with many countries that refuse to release micro data to any institution or individual. Such countries are quite diverse, ranging from Japan to Algeria. There is thus a paradoxical situation that a number of expensive instruments like household surveys exist in the world, yet they cannot be used because of misplaced policies of some countries' statistical offices. The issue of confidentiality with which they sometimes defend their practice is clearly bogus since no researcher can ever identify the participating households. Are we to believe that a researcher at (say) Cornell University in 2005 is going to identify the Japanese households that took part in a survey conducted in 1973?

${ }^{12}$ It has not always been like that. Consider the problems of converting Communist countries' national accounts methodology into NAS system, and of course the issue of deliberate falsification of national accounts.
} 
Another drawback is that the combination of GDI per capita with some distributional statistics (to reflect national income distribution) introduces a mixing of two aggregates, calculated from different sources, and this "mixing" is not distributionneutral. On the one hand, we are using as the country GDI per capita, and on the other, we are applying to this mean, distributional parameters obtained from surveys of household disposable income. ${ }^{13}$ It was already explained that the two instruments are different by definition. But in addition, such an adjustment is not distribution-neutral. We know that surveys tend to underrepresent capital income or undersurvey rich people (see Mistiaen and Ravallion, 2003). ${ }^{14}$ Thus, a simple upscaling of all survey incomes by a given parameter will reduce poverty below what it really is and underestimate inequality. ${ }^{15}$ When a different mean (GDI per capita) is applied to a survey-based distribution, we implicitly allocate the difference between GDI per capita and disposable household per capita income across all households (more exactly, in proportion to reported household income). Poor people's income is increased in the same proportion as rich people's income. But if most of the difference between the two concepts is due to unreported income of the rich then this approach artificially inflates incomes of the poor.

Now, income of the rich which accounts for the bulk of the difference between GDI and disposable income is of two types: first, the definitionally-different part which consists of publicly-financed health and education, corporate profits etc. that are

\footnotetext{
13 "The difference in coverage and definition between [National accounts] and survey means that, even if everything were perfectly measured, it would be incorrect to apply inequality or distributional measures, which are derived from surveys which measure one thing, to means which are derived from national accounts, which measure another (Deaton., 2003, p.35).

${ }^{14}$ Income from property is notoriously underestimated in household surveys (even leaving aside the fact that most surveys do not include capital gains at all). Concialdi (1997, p. 261) claims that the best available French household surveys underestimate capital incomes by about 40 percent. Wagner and Grabka (1999) estimate German property income to be underestimated by almost one-half compared to National Accounts data. In Japan, according to Ishizaki (1985) only 12 percent of property income is "captured" by household surveys (quoted in Bauer and Mason, 1992, p. 407).

${ }^{15}$ We speak of upscaling rather than downscaling because GDI per capita is normally greater than household per capita disposable income.
} 
consumed by the rich but also by the middle-classes and some poor in rich countries; ${ }^{16}$ second, income of rich people in each individual country that is missed out by surveys (for example, property incomes). All actual recipients of these incomes are globally-rich because the middle-class and even the poor from the rich world are in the top quintile of global income distribution, but the difference between the two aggregates is spread much more widely: some of it is imputed to the poor in the poor countries which, we know, receive none of it.

Consider the following example. Let the poverty line be \$PPP1 per capita per day. Let average per capita disposable income from surveys of several groups of the poor in India may be $\$ 0.75, \$ 0.8, \$ 0.85$. Now, suppose (very realistically) that India's GDI is some 35 percent higher than disposable income. We know that most of these 35 percent is received by the rich, either because they benefit from publicly-funded education or because they fail to report their property incomes. What the authors (in particular, Sala-iMartin, 2002 and Bhalla 2002) then do is to multiply incomes of the poor by the factor of 1.35. Then, suddenly, none of them is any longer poor: they have all crossed the poverty threshold! ${ }^{17}$

But if we decide that "income" in global studies should be the same concept as in national studies of inequality - that is household per capita disposable income - the problem is not solved yet. This is because national definitions of survey income are very different, and the more countries we include, the more different they become. A huge effort, conducted by Luxembourg Income Study, has gone into standardization of national definitions. A similar project is underway at the World Bank using Living Standards Measurement Surveys (LSMS). Yet the standardization covers only a small portion of all countries and surveys. The main differences arise in the treatment of selfemployed income (what are business expenditures for the self-employed?), valuation of

\footnotetext{
${ }^{16}$ Disposable household income retrieved from surveys in West European nations amounts to about 60 percent of GDI. A bulk of that difference is explained by health and education consumption. Publiclyfinanced health and education as share of GDI is much less in poor countries.

${ }^{17}$ On the additional pitfalls caused by the use of averages from national accounts and distributions from household surveys, see Ravallion (2000), Deaton and Dreze (2002), and Deaton (2003).
} 
home-consumption including owner-occupied housing,${ }^{18}$ treatment of publicly-provided health and education benefits, and the use of top-coding of high incomes (where all incomes above a certain ceiling are coded as equal to that ceiling). ${ }^{19}$ For different countries and at different levels of development, differences in the treatment of these categories are not equally important. For poor countries, it is the problems of valuation of own consumption and self-employed income that are the most difficult and that can make individual incomes often move up by a factor of 2 or more; for the rich countries, it is the treatment of publicly-provided health and education benefits that is of most concern. Swedish disposable income with them or without them is quite different. For countries with extravagantly rich individuals it is the underestimation of capital incomes which is of concern.

But there is no agreement that "income" in global inequality studies should be income at all. Many people think that rather than income, one should look at consumption or expenditures as the true indicator of the standard of living. This debate mirrors the debates that are waged in individual countries since obviously inequality can be measured using either income or consumption. What lends this debate an added importance in the case of global inequality is that in many countries household surveys ask income questions only, while in other countries they ask for both, or for expenditures only. Then, a global study of inequality has to do what all national studies try to avoid, that is to mix household survey data that use two different concepts of "income": disposable income and consumption. This introduces an error whose direction and magnitude cannot be estimated. Although in the last few years, there has been a trend toward the use of consumption measures (not the least through the efforts of the World Bank and the influence it exerted on the choice of survey instruments in the former communist countries and Africa), we are still far from unanimity on this issue. In the study of global

\footnotetext{
${ }^{18}$ For example, in 1990 Chinese statistical office changed the valuation of grain output produced by rural households from state-mandated to market prices. This generated a large change in the calculated poverty rates and a break in the rural mean income series (see Ravallion and Chen, 2005).

${ }^{19}$ For example, the US Current Population Survey top-codes all very high wage and capital incomes. Similarly, the maximum capital gain that can be recorded in the survey is $\$ 149,999$ per household annually.
} 
inequality based on the 1998 benchmark data, Milanovic (2005, p. 104) used 63 consumption instruments and 59 income instruments. This represents a significant increase in the number of consumption instruments compared with ten years before ( 80 income-based and 22 consumption-based distributions), but for some of the most important counties (like China) one still depends on income data alone. If a guess had to be ventured, it could be said that there is likely to be a tendency toward greater use of household per capita consumption as the welfare indicator. This, while quite defensible from a strictly methodological perspective, will open up a number of issues of comparability since most historical income distribution statistics (e.g. in the United States, UK, France, Germany) are income-based. One thus needs to balance methodological and quality improvements in the snapshots of today's income distribution against the break in the historically existing series.

After the problems of what is the proper welfare indicator, it would seem that other methodological issues should be easier to deal with. This is true. Whatever "income" is, that "income" should be expressed in per capita terms and should be equal across members of a household. This means that the two issues that are often debated in national inequality studies are "solved" here: the issue of equivalence scales, and intrahousehold inequality. These are "solved" because at the current level of statistical development, there is simply no way to account for economies of scale and size across different countries. The main reason for this is that economies of scale and size depend on relative prices of public and private goods (if housing is very cheap, economies of size will be small) and they systematically differ between poor and rich countries. ${ }^{20}$ Until we have a better handle on the relative prices of public and private goods, ${ }^{21}$ we cannot adjust internationally for equivalent units. A use of a given equivalence scale across all

\footnotetext{
${ }^{20}$ See Lanjouw, Lanjouw, Milanovic and Paternostro (2004).

${ }^{21}$ And also relative prices of children vs. adult goods if we are to adjust for household composition (and not only for household size).
} 
countries of the world would be much more arbitrary than the use of per capita calculations. Similarly, we lack any information about within-household inequalities. ${ }^{22}$

Another issue on which there is agreement is that whatever "income" is, it needs to be adjusted using a country's relative price level. In other words, we need to use PPP exchange rates to translate domestic currencies into international dollars. Ideally, of course, one would like to move toward a better adjustment where at least for some large countries with less than fully integrated markets, PPP exchange rates would differ between different parts of the country (e.g. the price level in the richest Chinese province is estimated to be 76 percent higher than in the poorest; see Brandt and Holz, 2006).

Another concern is that the relative prices faced by different parts of the income distribution are not the same. According to Pogge and Reddy (2002), relative food prices faced by the poor in poor countries are higher than what is implied by the use of a single all-consumption PPP. ${ }^{23}$ The food prices are what really matters for the poor, and the use of an overall (lower) price index will artificially boosts poor people's income in India or elsewhere in poor countries. ${ }^{24}$ Pogge and Reddy advocate a cross-country project akin to the one currently conducted by the World Bank's International Comparison Project which would generate PPPs relevant for the very modest, principally food, basket consumed by the poor across the world. But so long as within-country (provincial) PPPs and PPPs differentiated by income class are not available, we shall be obliged to use a single PPP exchange rate per country.

\footnotetext{
${ }^{22}$ Schultz (1998) however tries to account for intra-household inequality by using genders gap in schooling (for each country) to estimate gender gaps in income at the household level.

${ }^{23}$ The meaning of this sentence is that the ratio of food prices consumed by the poor in (say) Indonesia to the food prices of the same goods in the US is higher than the ratio between the overall price level in India and that in the US.

${ }^{24}$ This reason behind income overestimation is as follows. The weights in the "world" consumption basket of goods and services are decisively influenced by the prices and the structure of consumption in rich countries since they are obviously the largest consumers. Then, a relatively high consumption of services in poor countries (which are cheap there) but are assessed at much higher "world" prices tends to show poor countries' (and poor people's) income higher than it "really" is. One possible way to adjust for this is to move from the commonly used Geary-Khamis index which has the just explained property to more "neutral" price indexes (Afriat or EKS) where the weight of rich countries is less (see Dowrick and Akmal, 2001).
} 
How about the use of market (rather than PPP) exchange rates in global inequality calculations? This is a useful complement because it gives us a different insight into inequalities. If one is interested in global purchasing power or ability to affect the world economy, then conversion of local incomes into actual US dollars makes sense. But there are relatively few instances where we are interested in this, and most of our interest in global inequality is really based on the desire to compare living standards of different people. For that purpose PPP exchange rates are, of course, better.

\section{How big is global inequality?}

There is a general agreement about the size of global inequality, and there is a general disagreement about the recent direction of change of global inequality. Table 1 shows the results for global inequality obtained by a number of authors using quite different techniques: most of them mix national accounts information (using GDI per capita as mean income) and household survey information, and only a few use household surveys directly. In all the studies however, the recipients are individuals (inequality is expressed on a per capita basis), and national incomes are converted in international (PPP) dollars although the PPP exchange rates may be drawn form different sources. All Gini values for the 1990s, with the exception of the two extremes (61 and 71) lie within a relatively narrow range between 63 and 68 . The similarity in the results is even more remarkable when one realizes that the standard errors of these estimates are between 2 and 3 Gini points, ${ }^{25}$ and that consequently most of the estimates are within one standard error of each other.

As for the direction of change - comparison between the 1990s and 1980s - there is no unanimity. Sala-i-Martin and Bhalla, using very similar methodologies, argue that global inequality has declined by between 3 and 4 Gini points. Dikhonov and Ward, and Bourguignon and Morrison find an increase of about 1 Gini point. Sutcliffe concludes

\footnotetext{
${ }^{25}$ One has to be careful in the interpretation of the standard error. The standard errors are obtained using simple bootstrapping techniques so they basically show how sensitive is the estimated Gini coefficient to any single observation (Milanovic, 2002). These results do not include any information about the reliability of the underlying national income distributions (viz, how correctly incomes are measured).
} 
that there was no change, and Milanovic finds an increase of 3 Gini points between 1988 and 1993 followed by a decline of 1 Gini point in the next five years. ${ }^{26}$ His most recent (and unpublished) calculations for 2002, show another small increase of about 1 Gini point. Thus, according to Milanovic, there are zig-zags. They are explained, in the early 1990s, by the slow growth of rural incomes in India and China and economic collapse of Eastern Europe both of which contributed to global inequality. When both developments reversed in the next five-year period global inequality decreased. But these are zig-zags caused by specific economic events in large countries, not a trend.

This lack of unanimity on changes, and disagreement on whether there is any trend at all, stem not only from the differences in methodologies but paradoxically also from the very similar results that all authors obtain regarding the overall level of inequality. The reason is as follows. Different methodologies yield similar inequality levels but they do so with quite a lot of noise caused by measurement problems. Mean incomes, whether obtained from surveys or national accounts, are not consistently calculated and key data sources disagree among themselves. The computation of Concept 2 inequality using GDI per capita - a metric on which there is apparently least dispute_-from World Bank or Maddison's data series will differ by several Gini points. This is because, as pointed out by Sutcliffe (2003), Maddison's data include estimates for a number of war-torn or otherwise "excluded" countries like Sudan, Afghanistan, Somalia, the Congo, Cuba, North Korea etc. that are almost invariably poor and not included in the World Bank database. In addition, Maddison's growth rates for China are less than the official rates and those used by the World Bank. It is then not surprising that when one superimposes estimates of national distributions on one or another set of GDIs per capita to generate global inequality, the choice of the GDI database will clearly influence the end result. ${ }^{27}$

\footnotetext{
${ }^{26}$ World Bank's 2006 World Development Report uses mean log deviation as the measure of global inequality. It finds that it has decreased between 1994 and 2000 from 0.87 to 0.82 (see World Bank 2005, p.64).

${ }^{27}$ For example, Concept 2 inequality calculated using World Bank GDI per capita data from 138 countries shows a decrease of some 3 Gini points between 1985 and 2000. The same concept calculated using Maddison's data over the same period for about 160 countries shows a decline of only 1 Gini point (author's unpublished calculations).
} 
Income distribution data, particularly when extrapolated from quintiles or from the Gini coefficients, are even noisier. Furthermore, due to the absence of income distribution data for many countries, some authors (e.g., Bhalla and Sala-i-Martin) resort to very dubious assumptions, taking for example that income distributions either do not change in time or change in a certain (linear) fashion or even that everyone in a country has the same income. This myriad of assumptions and measurement errors in most cases tend not to bias the results in one direction only, but probably to offset each other, producing relatively similar levels of inequality. But when one re-estimates global inequality for another year, while the level hardly changes, the result is (on the account of the measurement error if nothing else) likely to be slightly different. It is that slight difference that is then interpreted as the evidence of a change, or in some cases even of a trend.

How big is a Gini of around 65? It is larger than inequality found in any single country including South Africa and Brazil, two among most unequal countries in the world, whose Ginis are in the upper fifties or low sixties. The Gini coefficient however does not give an intuitive feeling of how large global inequalities are. A better way to look at it is to consider how the overall pie is distributed across different fractiles of the distribution, Thus, for example, the top 5 percent of individuals in the world receive about $1 / 3$ of total world (PPP-valued) income, and the top 10 percent one-half. If we take the bottom 5 and 10 percent, they receive respectively 0.2 and 0.7 percent of world total income. This means that the ratio between the average income received by the richest 5 percent and the poorest 5 percent of people in the world is 165 to $1 .^{28}$ The richest people earn in about 48 hours as much as the poorest people earn in a year.

Another important question is to ask how much of global inequality is due to differences in mean incomes of countries and how much to income differences within countries. Some 70 percent of global inequality is "explained" by differences in

\footnotetext{
${ }^{28}$ This is based on Milanovic (2005).
} 
countries' mean incomes. This is a sharp reversal from a situation which existed around the time of the Industrial Revolution when more than half of the (admittedly very rough) estimate of global inequality was due to income differences within nations (see Bourguignon and Morrisson, 2002). ${ }^{29}$ Then, in contrast to today, the differences between countries' mean incomes were relatively small. For example in 1870, the average (unweighted) GDI per capita of the ten richest countries was 6 times greater than the average (unweighted) GDI per capita of the ten poorest countries. In 2002, the ratio was 42 to $1 .{ }^{30}$

While income inequality between countries is the largest component of global inequality, overlaps between countries' distributions (that is, some people from a poor country being better off than some people from a rich country) are non-negligible either. ${ }^{31}$ We illustrate this in Figure 1 which plots the position of each 5 percent (ventile) of different countries' distributions in the global distribution. Consider the line for France. We calculate the mean income (in international dollars) of each French ventile from the lowest (first) to the highest — arrayed on the horizontal axis — and then find their positions in global income distribution. As can be seen, the poorest 5 percent of Frenchmen have a mean income which places them at the $72^{\text {nd }}$ percentile of world income distribution; the richest 5 percent have an income which places them in the top percentile of the world. Hence French income distributions spans the range between the $72^{\text {nd }}$ and $100^{\text {th }}$ percentile in the world. Consider now rural Indonesia in the bottom of the figure. Here the span is from the $4^{\text {th }}$ percentile in the world to the $56^{\text {th }}$ percentile. The

\footnotetext{
${ }^{29}$ This is an estimate based on the Theil decomposition between inequality due to the differences in incomes between six country groups, namely (Africa), (Asia), (Japan, Korea and Taiwan), (Latin America), (Eastern Europe), and (Western Europe and its offshoots) and inequality within country groups. Since there are no data on income distributions for most countries in the world prior to 1950, Bourguignon and Morrison use estimates for a few select countries to "impart" the same distributions to other countries in the group. Their between-component accounts for some 30 percent of global inequality. Obviously, if they had data on all countries' distributions, the between component would have been larger. However it is unlikely to have exceeded one-half of global inequality.

${ }^{30}$ Both calculated from Maddison (2004) data.

${ }^{31}$ Note that in a world of large between-county income differences, and very small within-national inequalities, there would be no overlap at all, and $100 \%$ of global inequality would have been "caused" by between-national differences.
} 
two distributions (French and rural Indonesian) do not overlap at all. ${ }^{32}$ But this is not the case if we compare Brazil and France: more than a third of all Brazilians are richer than the poorest 5 percent of the French. ${ }^{33}$

The figure illustrates not only that inequality due to within-national distributions is still significant and that countries are not homogeneous entities composed of either rich and poor people only but will have practical implications when we discuss global transfers (see Section 5). In short, if transfers were to flow from mean-income rich to mean-income poor countries, and we do not a priori know who their beneficiaries are, a glance at Figure 1 immediately convinces us of a need to take recipient countries' income distributions seriously. This is because the probability that money raised from a French citizen will end up in the pockets of somebody who is richer than he is higher if money is transferred from France to Brazil than if it is transferred from France to rural Indonesia. But to this topic we shall return below.

\footnotetext{
${ }^{32}$ This is of course true at the level of ventiles. It is quite possible, even likely, that there are some individuals in rural Indonesia who are richer than some individuals in France. If we conducted the analysis in terms of national percentiles rather than ventiles, there would be some overlap. But it would be clearly minimal.

${ }^{33}$ Even if at each given ventile, income of the French is higher than the income of the Brazilians. The last statement means that French income distribution is first-order dominant over the Brazilian distribution (as is for example Sri Lankan over the rural Indonesia) even though the French and Brazilian distributions do overlap (unlike the French and rural Indonesian).
} 
Figure 1. The position of different countries' ventiles in global income distribution

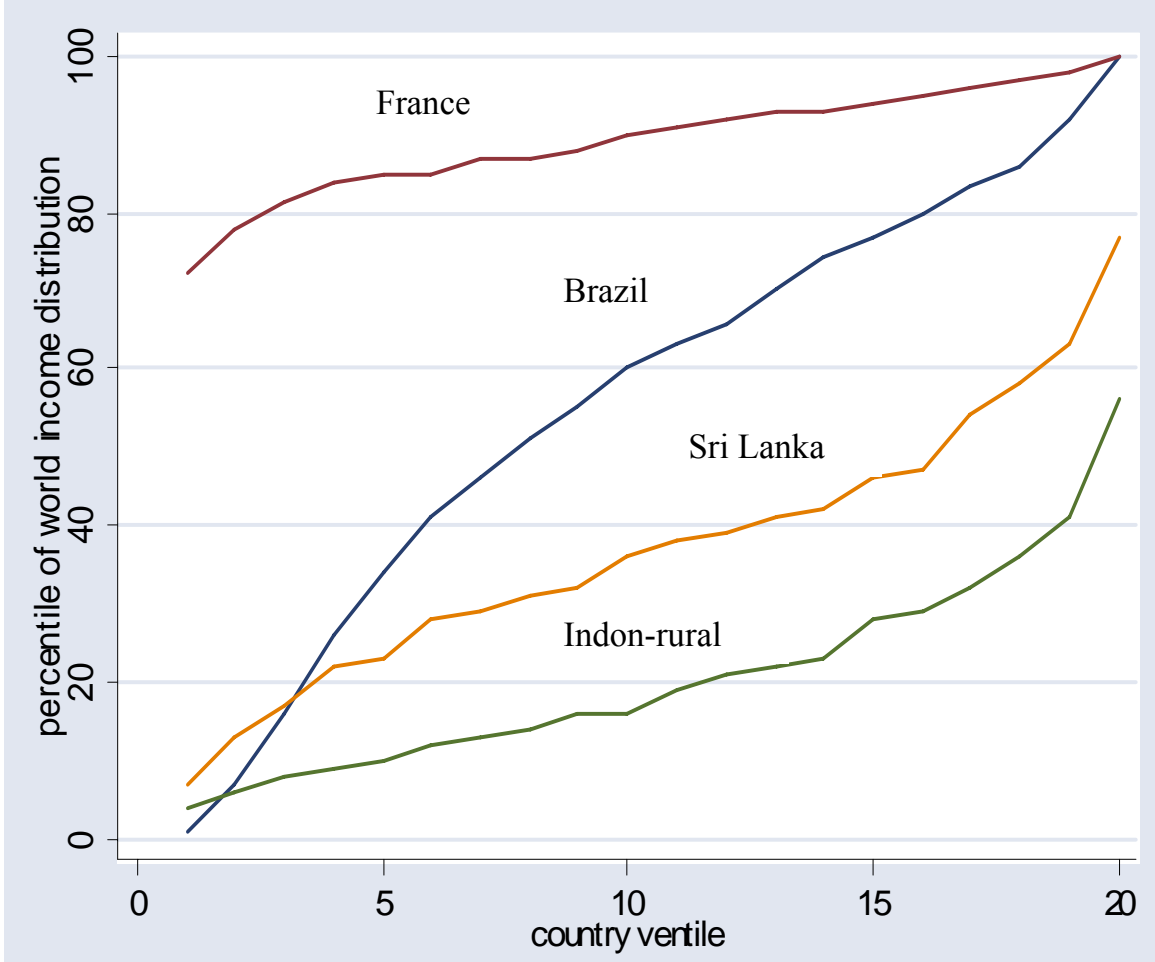

Source: Calculated from World Income Distribution (WYD) data. Available at http://econ.worldbank.org/projects/inequality. 
Table 1. Global inequality (in Gini points) in 1990s, according to various authors

\begin{tabular}{|c|c|c|c|c|}
\hline Author & Year & Gini value & $\begin{array}{l}\text { National mean } \\
\text { incomes from: }\end{array}$ & $\begin{array}{l}\text { National } \\
\text { income } \\
\text { distributions } \\
\text { from: }\end{array}$ \\
\hline $\begin{array}{l}\text { Milanovic } \\
(2005)\end{array}$ & 1993 & 66 & $\begin{array}{l}\text { Household } \\
\text { surveys }\end{array}$ & $\begin{array}{l}\text { Household } \\
\text { surveys }\end{array}$ \\
\hline $\begin{array}{l}\text { Milanovic } \\
(2205)\end{array}$ & 1998 & 65 & $\begin{array}{l}\text { Household } \\
\text { surveys }\end{array}$ & $\begin{array}{l}\text { Household } \\
\text { surveys }\end{array}$ \\
\hline $\begin{array}{l}\text { Bourguignon } \\
\text { and Morrison } \\
(2002)\end{array}$ & 1990’s & 66 & $\begin{array}{l}\text { GDI } \\
\text { (Maddison) }\end{array}$ & $\begin{array}{l}\text { Household } \\
\text { survey } \\
\text { estimates }\end{array}$ \\
\hline $\begin{array}{l}\text { Sala-i-Martin } \\
(2002)\end{array}$ & 1998 & 61 & $\begin{array}{l}\text { GDI } \\
\text { (PennWorld } \\
\text { Tables) }\end{array}$ & $\begin{array}{l}\text { Ginis and } \\
\text { quintiles from } \\
\text { HS }\end{array}$ \\
\hline Bhalla (2001) & 2000 & 65 & $\begin{array}{l}\text { GDI } \\
\text { (PennWorld } \\
\text { Tables and } \\
\text { WDI) }\end{array}$ & $\begin{array}{l}\text { Ginis and } \\
\text { quintiles from } \\
\text { HS }\end{array}$ \\
\hline $\begin{array}{l}\text { Dikhanov and } \\
\text { Ward (2001) }\end{array}$ & 1999 & 68 & $\begin{array}{l}\text { National } \\
\text { consumption } \\
(\text { WDI) }\end{array}$ & $\begin{array}{l}\text { Ginis and } \\
\text { quintiles from } \\
\text { HS }\end{array}$ \\
\hline $\begin{array}{l}\text { Dowrick and } \\
\text { Akmal (2001) }\end{array}$ & 1993 & 71 & GDI & $\begin{array}{l}\text { Ginis and } \\
\text { quintiles from } \\
\text { HS }\end{array}$ \\
\hline Sutcliffe (2003) & 2000 & 63 & $\begin{array}{l}\text { GDI } \\
\text { (Maddison) }\end{array}$ & $\begin{array}{l}\text { Ginis and } \\
\text { quintiles from } \\
\text { HS }\end{array}$ \\
\hline $\begin{array}{l}\text { Chotikapanich et } \\
\text { al. (1997) }\end{array}$ & 1990 & 65 & $\begin{array}{l}\text { GDI } \\
\text { (PennWorld } \\
\text { Tables) }\end{array}$ & Ginis for HS \\
\hline
\end{tabular}

Note: HS=household survey; GDI=Gross Domestic Income. WDI=World Development Indicators (World Bank). 
4. Is there a link between globalization and global inequality?

It is often implicitly assumed that the results regarding the change in global inequality can be interpreted as telling us whether globalization leads to widening or shrinking of income differences between individuals in the world. ${ }^{34}$ While, in the most abstract way, this is true the causal link between globalization and global inequality is very difficult to make. To see this, consider several ways in which globalization affects inequality among individuals in the world. ${ }^{35}$

The first channel goes through globalization's effects on within-national distributions. As we would expect from economic theory, the effect varies between rich and poor countries. In the simplest Heckscher-Ohlin world, globalization would increase demand for, and wages of, low-skilled labor in poor countries and wages of high-skilled workers in the rich world. Consequently, we would expect income distribution in poor countries to become "better" and that in rich countries to get "worse." This is not however consistent with what was observed over the last twenty years when distributions in poor, middle-income and rich countries have tended to grow more unequal (Cornia and Kiiski, 2001). This is an issue which has recently been studied a lot and is still a subject of intense debate: is openness to blame for increasing wage and income differences in the US?; is openness associated with rising income inequality in poor countries? For example, Milanovic (2005) and Ravallion (2001) find that openness is associated with increased inequality in poor countries, and lower inequality in rich countries, while

\footnotetext{
${ }^{34}$ Most often, globalization is defined in terms of two outcome variables: increased share of trade in GDI and increased share direct foreign investments in GDI. This is quite acceptable when we have income inequality as the dependent variable since inequality moves in response to outcomes (higher or lower trade). But one could also define globalization in terms of policies (e.g., lower trade barriers).

${ }^{35}$ The objective here is not to review the immense literature in any of these areas but just to give a brief sketch of the issues and what the key agreements and disagreements are..
} 
Dollar and Kraay (2002) argue that there is no systematic effect of openness on inequality. ${ }^{36}$

Then, and this is the second channel, globalization may affect differently mean incomes of poor and rich countries: in other words, it might lead to divergence or convergence in country incomes. There is no unanimity on this point either. Most authors agree that openness is positively associated with mean income growth (Balassa, 1985; Edwards, 1998) but some of them (Sachs and Warner, 1997; World Bank 2002) find the effect stronger for poor countries while others (DeLong and Dowrick, 2003; Dowrick and Golley, 2004) argue that the openness premium during the last twenty years has been larger for rich than for poor countries. ${ }^{37}$ The first group of authors would expect openness to lead to shrinking differences in national mean incomes. Therefore they have to explain away the observed divergence in mean country incomes by the lack of openness among the laggards. According to the second group of authors, the divergence is an indication that the effects of openness might change over time and that openness, even if on balance positive for all, may exacerbate inter-country inequality.

Third, the effects of globalization may vary between populous and small countries. This area has not been much explored except within the context of the rather limited (in scope and number) studies of small island economies. Yet one can imagine that globalization may play out differently in populous countries with large domestic markets, or in small niche economies like Hong Kong, Singapore or Luxembourg than in middle-size countries.

And finally, and possibly most importantly, the effect of globalization on global inequality will depend on history, that is on whether populous countries happen to be at a

\footnotetext{
${ }^{36}$ For a review of the literature see Winters, McCulloch, and McKay (2004), and Milanovic (2005a). The role of trade in increasing wage differentials in rich countries is the subject of voluminous controversy (for some examples see Freeman 1995, and Slaughter 1999).

${ }^{37}$ According to them, the openness premium was larger for poor countries in the $1960-80$ period but then changed in the last twenty years. For some speculations what might have triggered that change see Dowrick and Golley, 2004, p. 53).
} 
given point in time poor or rich. To see this, assume for a moment that globalization has a positive impact on growth rates of populous and poor counties and has no effect on within-national income distributions. This will, in the current constellation of world incomes (see Figure 2), mean that India and China would be expected to catch up with the rich world while their national distributions will not change, and that global inequality will tend to decrease. ${ }^{38}$ There would be both mean-income convergence and reduction of global inequality.

But decouple the poor and populous countries. Suppose that India and China are rich (and still populous) and let most of poor countries be relatively small. Now, meanincome convergence will continue, but the effect on global inequality will be ambiguous. China and India will benefit from the pro-big bias of globalization but since they would be rich, globalization will be less beneficial to them than to poor countries. These two effects will pull in the opposite directions and global inequality may go down or up. Moreover, if populous countries are generally poor, the convergence effect is nil, globalization on average favors small countries, and leads to the widening of national income distributions, then the overall effect must be to increase global inequality.

This illustrates a key point: even if the effects of globalization on (i) withinnational inequality, (ii) mean-income convergence, and (iii) populous vs. small countries are unambiguous and do not change over time, globalization's impact on global inequality will vary in function of where along international income distribution countries with different attributes happen to lie at a given point in time. The implication is of course that all statements about the relationship between globalization and global inequality are highly time-specific, contingent on past income history, and not general.

\footnotetext{
${ }^{38} \mathrm{We}$ are concerned with effects at one point in time only. Independent changes in population may, by affecting the weights in the inequality statistics, influence on their own changes in global inequality. For example, China's impact on global inequality can be decomposed between income per capita growth and population growth effects. Jiang (2006) finds that one-third of China's contribution to reducing global inequality is due to its population growth.
} 
Figure 2. Distribution of people according to GDI per capita of the country where they live (year 2000)

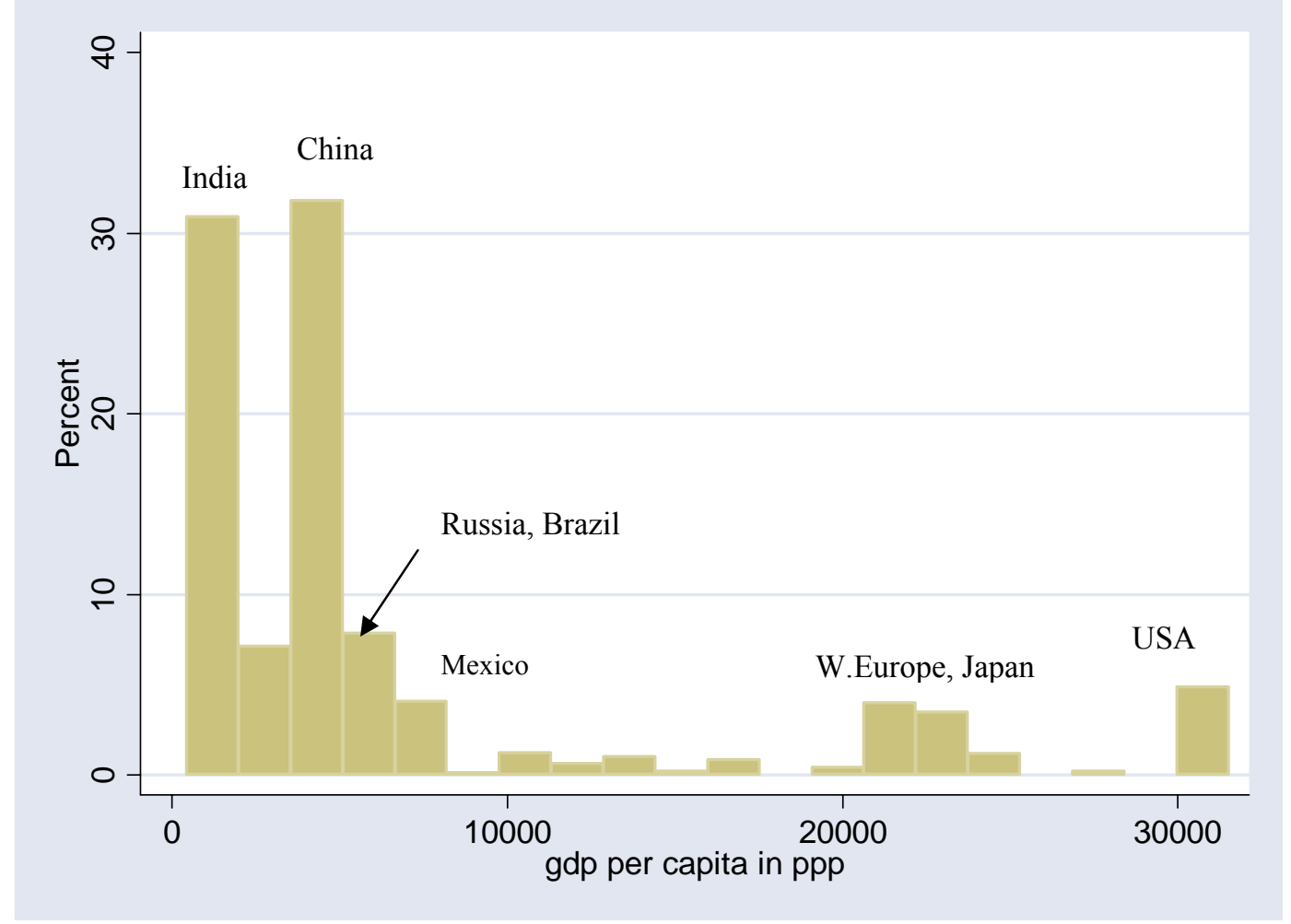

Note: horizontal axis: GDP per capita in 1995 international prices; vertical axis: share of world population. Source: Milanovic (2005, p. 94). 
5. Does global inequality matter?

There are two views on this matter (as pretty much on everything else discussed here). One group of people believe that global inequality is irrelevant. There are two reasons why it may be so. According to Bhagwati (2004) even a calculation of global inequality is a "lunacy." It is a mere number. There is no "addressee" to whom this mere number matters because there is no global government and there is no global civil society. According to this view, national inequalities matter because they become the stuff of political discourse; they are used to form political parties, platforms, to organize interest groups. But at the global level none of that exists because there is no global polity. Another reason adduced for the irrelevancy of global (or for that matter, all) inequality is that only changes in absolute income matter to the poor and the rich alike (Krueger 2002, Feldstein 1999). In words of Ann Krueger (2002) "Poor people are desperate to improve their material conditions...rather than to march up the income distribution [ladder]." Thus even if the absolute income gap between an average American and an average African increases, these authors are unconcerned. After all, they argue, the average African would be a bit less poor. This of course assumes that our income relative to the income of others does not matter. Yet this conclusion is at odds with psychological studies that invariably show that people do not care only about their absolute dollar income but also about where they stand in the social pyramid, and also whether they think this position to be fair (Graham and Felton 2005, Frank 2005) ${ }^{39}$

Or — differently—global inequality may matter. On this side of the issue, there are also different approaches. For Pogge and Reddy (2002) and Singer (2002) global poverty and global inequality are ethical issues. Hence the rich world cannot disown all interest in global poverty and inequality: to some extent, the fate of every individual in the world affects us. Distributional justice within a nation and in the world as a whole are, from an ethical perspective, the same thing (see Singer 2002, Chapter 5).

\footnotetext{
${ }^{39}$ Not surprisingly, rich people have less aversion to inequality (see for example, the results reported in World Bank, 2005, p. 84).
} 
There are also more pragmatic reasons why global inequality may matter. Kuznets (1965 [first published in 1954], pp. 173-4) formulated it some fifty years ago: "Since it is only through contact that recognition and tension are created, one could argue that the reduction of physical misery associated with low income and consumption levels...permit[s] an increase rather than a diminution of political tensions [because] the political misery of the poor, the tension created by the observation of the much greater wealth of other communities...may have only increased." When people observe each other and interact, it is no longer simply a national yardstick that they have in mind when they compare their income with the income of others, but an international or global one. What globalization may do is to increase the awareness of other people's income and therefore the perception (knowledge) of inequalities among both the poor and the rich. If it does among the poor, then their aspiration level changes: they may no longer be satisfied with small increases in their own real income if they know that other people are gaining much more. ${ }^{40}$ Therefore the process of globalization by itself may change the perception of one's position, and even if globalization were to raise everybody's real income, it could exacerbate, rather than moderate, feelings of despondency and deprivation among the poor.

Globalization in that sense is no different from the process which led to the creation of modern nation states out of isolated, and often mutually estranged, hamlets. National income distribution was similarly an abstraction for the people who did not interact with each other, and almost ignored each others' existence and way of life. However once nation-states came into existence, national inequality became an issuesimply because people were able to compare their own standard of living and to make judgments whether these income differences were deserved or not. If one believes that the process of globalization would slowly lead toward the formation of a global polity then global inequality will indeed become a relevant issue. For it is difficult to envisage that a fully free exchange of goods, technology and information, transfer of capital, and

\footnotetext{
${ }^{40}$ This is of course a conjecture. We do not have, as far as I know, any studies that look at the effect of international consumption on domestic perception of well-being. It is an area worth further research.
} 
some freedom in the movement of people can go on for a long time without creating global polity and requiring decision-making processes at the global level.

If so, then we need to develop some rules for global redistribution. A caveat is in order here. Large income differences in the world are due, as we have seen, mostly to the large differences in countries' mean incomes. And since the early 1980s, many countries of the world, and often among the poorest, have witnessed a systematic growth failure. Thus, to reduce income differences among individuals, increasing the growth rate in poor countries is of paramount importance. Granted the importance of growth, and for any given constellation of countries' growth rate, there may still be a need (desire?) to reduce income disparities through global redistribution. To guide these redistribution policies, we need to define some simple rules.

The first rule which may be called Progressivity 1 rule (a companion to Concept 1 inequality) is that funds should flow from a (mean-income) rich to a (mean-income) poor country. This requirement is easily satisfied. Even today bilateral aid is given by rich to poor countries (not the other way round). But in a global world, this is not enough.

Redistribution needs to be globally progressive - that is, to satisfy the same criteria that we require from redistribution within a nation-state. This means that the tax-payer ought to be richer than the beneficiary of the transfer. But both Progressivity 1 and global Progressivity may be satisfied (as shown in Figure 3 by points $B_{1}$ and $T_{1}$ ) while the beneficiary is a relatively rich individual in a poor country and the tax payer a relatively poor individual in a rich country. And it is precisely the perception that many transfers end up in the pockets of the rich elite in poor countries which is fueling the current discontent with multilateral and bilateral aid. Thus the third requirement ought to be that transfers be such that inequality decreases in both countries, donor and recipient. This will happen only if the tax payer is relatively rich even within his/her own country and the beneficiary is relatively poor in his/her country. This situation is illustrated by points such as $\mathrm{T}_{2}$ and $\mathrm{B}_{2}$. 
Figure 3. Globally progressive transfer

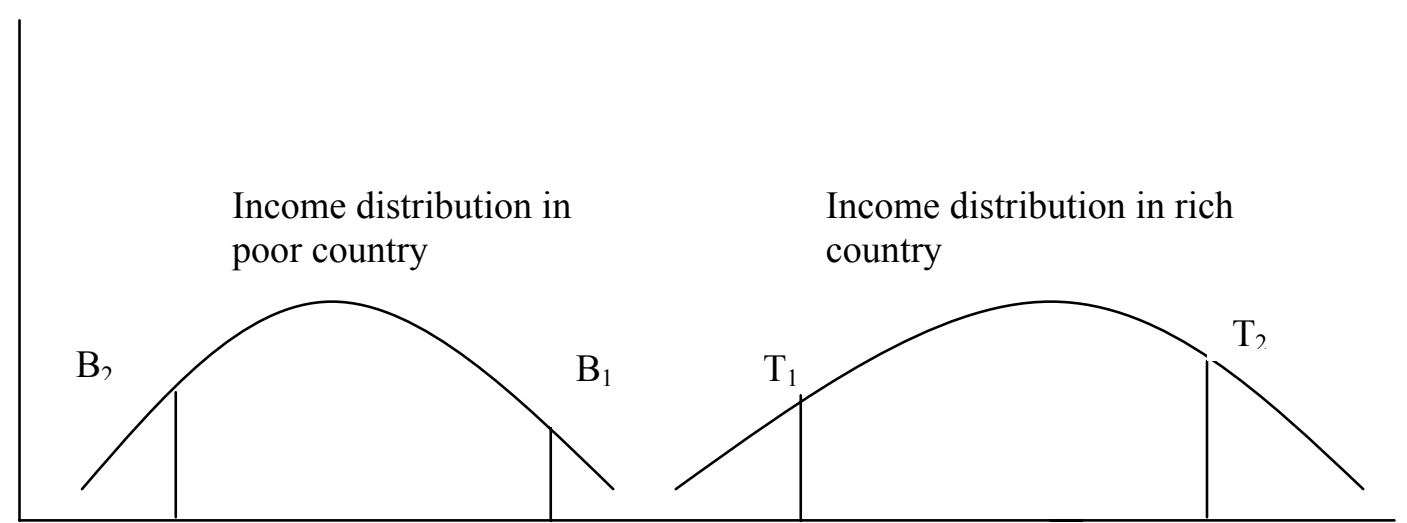

Income

Note: $\mathrm{T}=$ tax payer. $\mathrm{B}=$ beneficiary.

Now, these three requirements regarding global transfers will be more easily satisfied when income distributions of rich and poor nations do not overlap. This is for example the case of France and rural Indonesia (illustrated in Figure 1). Even if the distribution of aid money among Indonesian beneficiaries is random, global progressivity will be satisfied since there are practically no people in rural Indonesia who are better off than even the poorest Frenchmen. But this is not the case if we look at a transfer between France and Brazil. There, assuming that the tax payer belongs to the French middle class (say, around the median of French income distribution), a purely random allocation of aid to Brazil will still yield a non-negligible probability of 10 percent for a globally regressive transfer. ${ }^{41}$ This means that in the design of global transfers, one needs to take into account national income distributions, and working behind the veil of uncertainly regarding as to who exactly the beneficiaries of aid are, give preference to poor and egalitarian countries since transfers to them are unlikely to be globally regressive.

\footnotetext{
${ }^{41}$ Differently put, 10 percent of Brazilians have higher income than the median Frenchman.
} 
This is all of course under the assumption that we do not have any information about the distribution of benefits. But one can do better by trying to target the benefits toward the poor in poor countries. How could it be done? By creating a global body (Agency) that would be financed by a tax raised from the rich in rich countries (that is, a tax on goods or activities with very high income elasticity) and which would transfer these funds to poor individuals in poor countries. A global redistribution through taxes that would be levied by an international body is an idea that may seem far-fetched today, but which the logic of development we have recently witnessed - away from the nation state - suggests may eventually come to pass. Such a body should not be another intergovernmental organization like the United Nations or the World Bank. Indeed the new agency should take its cues from globalization. If it is empowered to raise its own funds, it should also eschew dealing with governments that have often wasted foreign aid. Instead, in the spirit of global citizenship, it should deal directly with national NGOs and individual citizens in poor countries and distribute collected funds in the form of cash grants. Notice that the Agency introduces a symmetry in its relations with the rich and poor countries. It takes away some of rich countries' sovereignty (since it dilutes their tax-raising power) but also takes away some of poor countries' sovereignty since it helps poor citizens in those countries directly and without requiring an authorization from their governments.

One such opportunity which was missed in the early 1990s may illustrate what I have in mind here. When Russia faced its worst crisis, aid, instead of being given to the corrupt Yeltsin regime, should have been disbursed directly in cash to the most needy citizens - for example, pensioners whose earnings plummeted due to inflation and the general chaos. An international organization, like the one we have in mind here, could have simply used the existing infrastructure of the Russian state, pension rolls, and distributed cash grants to some 20 million Russian pensioners. That would be money much better spent than giving the same amount to the government. And citizens would have fondly remembered receiving cash aid from the international community rather than blaming that same international community for transferring funds to corrupt leaders. Today, the same or similar approach could be applied in many countries, from Angola to 
Zimbabwe. The approach is simple and powerful. It involves three steps: raise money from the globally rich, do not deal with governments of either rich or poor nations, and transfer funds in cash to the poor.

While the supporters of an exclusively private-sector driven globalization may resent the idea of vesting tax-raising authority for the first time in history into a global agency, they cannot fail to notice that the very process they support undercuts, in an ironic twist, their own position. It does so by rendering the gap in wealth more obvious, and the fairness of the existing global distribution, more questionable. They will ultimately realize that their self-interest lies in supporting some form of global action to deal with both poverty... and inequality. 


\section{REFERENCES}

Atkinson, Anthony B. and Andrea Brandolini (2004), "Global world inequality: Absolute, relative or intermediate", Paper prepared for the $28^{\text {th }}$ Conference of the International Association for Research in Income and Wealth, Cork, Ireland, August 2228, 2004.

Balassa, Bela (1985), "Exports, policy choices and economic growtrh in developing economies after the 1973 oil shock", Journal of Development Economics, vol. 18 , No. 1, pp. 23-35.

Bauer, John and Andrew Mason (1992), "The distribution of income and wealth in Japan”, Review of Income and Wealth, vol. 38. no. 4, pp. 403-428.

Baumol, William (1986), "Productivity growth, convergence, and welfare: What the long-run data show", American Economic Review, vol. 76, December, pp. 1072-1116.

Berry Albert, Francois Bourguignon, and Christian Morrisson (1983), "Changes in the world distribution of income between 1950 and 1977', Economic Journal, vol. 93, June, pp. 331-50.

Bhagwati, Jagdish (2004), In defense of globalization, Oxford University Press.

Bhalla, Surjit (2002), Imagine There is No Country, Washington, D.C: Institute for International Economics.

Boltho, Andrea and Gianni Toniolo (1999), "The assessment: the twentieth century-achievements, failures, lessons”, Oxford Review of Economic Policy, vol. 15 (Winter), No. 4, pp.1-17.

Bourguignon, Francois and Christian Morrisson (2002), "The size distribution of income among world citizens, 1820-1990”, American Economic Review, September, pp. 727-744.

Brandt, Loren and Carsten Holz (2006), "Spatial price differences in China: Estimates and implications", Economic Development and Cultural Change, forthcoming. Available at http://ihome.ust.hk/ _socholz/SpatialDeflators.html.

Capeau, Bart and Andre Decoster (2004), "The rise or fall of world inequality: A spurious controversy", WIDER Discussion paper No. 2004/02. Available at http://www.wider.unu.edu/publications/publications.htm. 
Chotikapanich, D., Valenzuela, R. and Rao, D.S.P. (1997). "Global and regional inequality in the distribution of income: estimation with limited and incomplete data." Empirical Economics, vol. 22, pp. 533-546.

Concialdi, Pierre (1997), "Income distribution in France: the mid 1980s turning point" in Changing patterns in the distribution of economic welfare. An international perspective, edited by Peter Gottschalk, Bjorn Gustafson, and Edward Palmer, Cambridge University Press, pp. 239-264.

Cornia, Giovanni Andrea and Sampsa Kiiski (2001), "Trends in Income Distribution in the post WWII Period: Evidence and Interpretation" WIDER Discussdion paper 2001/89. Available at http://www.wider.unu.edu/research/1998-19993.1.publications.htm. Revised version published in Giovanni Andrea Cornia (ed.), Inequality, growth and poverty in an era of liberalization and globalization, UNUWIDER and Oxford University Press, 2004, pp. 26-56.

Deaton, Angus (2003), "Measuring poverty in a growing world (or measuring growth in a poor world)", NBER Working Paper 9822, June. Available at http://www.wws.princeton.edu/ deaton/working.htm. Revised version published in Review of Economics and Statistics, vol. 1, pp. 1-19, February 2005.

Deaton, Angus and Jean Drèze (2002), "Poverty and inequality in India: A reexamination", Economic and Political Weekly, September 7, 2002, pp.3729-3748.

DeLong, Bradford and Steve Dowrick (2003), "Globalization and convergence", Ch. 4 in M. Bordo, A.M. Taylor and J. Williamson (eds.), Globalization in Historical Perspective", Chicago: Chicago University Press.

Dikhanov, Yuri and Michael Ward (2001), "Evolution of the global distribution of income, 1970-99”, August 2001 draft.

Dollar, David and Aart Kraay (2002), "Growth is good for the poor", Journal of Economic Growth, vol. 7, pp. 195-225.

Dowrick, Steve and Jane Golley (2004), "Trade openness and growth: Who benefits", Oxford Review of Economic Policy, vol. 20, No. 1, pp. 38- 56.

Dowrick, Steve and Muhammed Akmal (2001), "Contradictory trends in global income inequality: A tale of two biases”, draft 29 March 2001, available from http://ecocomm.anu.edu.au/economics/staff/dowrick/dowrick.html, published in Review of Income and Wealth, June 2005, vol. 51, No. 2, pp. 201-230.

Edwards, Sebastian (19998), "Openness, productivity and growth: what do we really know”, Economic Journal, pp. 383-398. 
Feldstein, Martin (1999), "Reducing poverty not inequality", Public Interest, Fall 1999, pp. 34-43.

Firebaugh, Glenn (2003), The New Geography of Global Income Inequality, Cambridge, Mass.: Harvard University Press.

Frank, Robert H. (2005), "Positional externalities cause large and preventable welfare losses", American Economic Review Papers and Proceedings,. Vol. 95. No. 2, pp. 137-151.

Freeman, Richard B. (1995), “Are your wages set in Beijing?", Journal of Economic Perspectives, vol. 9 (Summer), No. 3, pp. 15-32.

Graham, Carol and A. Felton (2005), "Does inequality matter to individual welfare? An exploration based on household surveys in Latin America", Center on Economic and Social Dynamics Working paper series No. 38,. Brookings Institutions, Washington D.C.

Grosh, Margaret E. and E. Wayne Nafziger (1986), "The computation of world income distribution", Economic Development and Cultural Change, vol. 34, pp. 347-359.

Ishizaki, Tadao (1985), "Is Japan's income distrribution equal? An international comparison”, Japanese Economic Studies, vol. 14, No. 2, pp. 30-55.

Jiang Zhiyong (2006), "China component in international income inequality", Population Research and Policy Review, forthcoming.

Kravis, Irving, Alan Heston and Robert Summers (1978), "Real GNP per capita for more than one hundred countries", Economic Journal, vol. 88, pp. 215-242.

Krueger, Anne O., (2002), "Supporting globalization", Remarks at the 2002 Eisenhower National Security Conference on "National Security for the $21^{\text {st }}$ Century: Anticipating Challenges, Seizing Opportunities, Building Capabilities"

September 26, 2002. Available at http://www.imf.org/external/np/speeches/2002/092602a.htm.

Kuznets, Simon (1965), Economic Growth and Structure: Selected Essays, New Delhi: Oxford \& IBH Publishing Company.

Lanjouw, Jean, Peter Lanjouw, Branko Milanovic and Stefano Paternostro. "Relative price shifts, economies of scale and poverty during economic transition", Economics of Transition, vol. 12, September 2004, pp. 509-536.

Maddison, Angus (2004), "World population, GDP and GDP per capita, 1-2000 AD”. Available at http://www.eco.rug.nl/ $\sim$ Maddison/. 
Milanovic, Branko (2002), "True world income distribution, 1988 and 1993: First calculations based on household surveys alone", Economic Journal, vol. 112, No. 476, January, pp. 51-92.

Milanovic, Branko (2002a), "The Ricardian vice: Why Sala-i-Martin's calculations of world income inequality are wrong", mimeo. Available on www.ssrn.com.

Milanovic, Branko (2005), Worlds Apart: Global and International Inequality 19502000, Princeton University Press.

Milanovic, Branko (2005a), "Can We Discern the Effect of Globalization on Income Distribution? Evidence from Household Budget Surveys", World Bank Economic Review, April, No. 1, 2005, pp. 21-44.

Mistiaen, Johan and Martin Ravallion (2003), "Survey compliance and the distribution of income”, World Bank Working Paper No. 2956, January.

Pogge, Thomas W. and Sanjay Reddy (2002), "Unknown: The extent, distribution, and trend of global income poverty”, version July 26. Available at http://www.columbia.edu/ sr793/povpop.pdf.

Quah, Danny (1999), “6 x 109: Some dynamics of global inequality and growth”, typescript, December 1999, available from < http://econ.lse.ac.uk/staff/dquah/p/9912sbn.pdf>

Ravallion, Martin (2000), "Should poverty measures be anchored to the national accounts?" Economic and Political Weekly, 34 (August 26), pp. 3245-3252.

Ravallion, Martin (2001), "Growth, inequality and poverty: looking beyond averages", World Development, vol. 29, n11, November, pp.1803-15

Ravallion, Martin (2004), "Competing concepts in inequality debate", Brookings Trade Forum 2004, Brookings Institution: Washington, pp. 1-23.

Ravallion, Martin and Shaohua Chen (2006). "China's (uneven) progress against poverty”, Journal of Development Economics, forthcoming.

Sachs, Jeffrey and David Warner (1997), "Fundamental sources of long-run growth", American Economic Review, vol. 87, No. 2, pp. 184-188.

Sala-i-Martin, Xavier (2002), “The Disturbing 'Rise' of World Income Inequality”, NBER Working paper No. 8904, April. Available at www.nber.org.

Sala-i-Martin, Xavier (2002a), “The World Distribution of Income”, NBER Working paper No. 8905, May. Available at www.nber.org. 
Schultz, T. P. (1998). "Inequality in the distribution of personal income in the world: how it is changing and why." Journal of Population Economics, vol. 11, No. 3, pp. 307-344.

Singer, Peter (2002), One World: The Ethics of Globalization. New Haven, USA: Yale University Press.

Slaughter, Matthew (1999), "Globalization and wages: A tale of two perspectives”, World Economy, vol. 22, n5, July, pp. 609-29.

Sutcliffe, Bob (2003), "A more or less unequal world? World income distribution in the $20^{\text {th }}$ century", University of Massachusetts Amherst, Political Economy Research Institute, Working Paper Series, No. 54. Published as "World Inequality and Globalization”, Oxford Review of Economic Policy, vol. 20, No. 1, pp. 15-37.

Svedberg, Peter (2003), "World income distribution: which way", Institute for International Economic Studies, Stockholm. Published in Journal of Development Studies, vol. 40, No. 5, June 2005, pp. 1-32.

Wagner, Gert and Markus Grabka (1999) "Robustness assessment report (RAR) Socio-Economic Panel 1984-1998”, German socio-economic Panel, Berlin. Available from http://www.lisproject.org/techdoc/ge/ge94survey.doc.

Winters, Alan, Neil McCulloch and Andrew McKay (2004), "Trade liberalization and poverty: Evidence so far", Journal of Economic Literature, vol. 42, March, pp. 72115.

World Bank (2002), Globalization, Growth and Poverty: Building an Inclusive World Economy, Policy Research Report, Washington, D.C.: World Bank.

World Bank (2005), World Development Report 2006: Equity and Development, World Bank and Oxford University Press: Washington. 